\title{
URBAN FAMINE OR URBAN CRISIS? TYPHUS IN THE VICTORIAN CITY
}

\author{
by
}

\begin{abstract}
ANNE HARDY*
There were four horsemen of the Apocalypse: War, Famine, Disease and Death, a historic association which has continued into modern times. For most of history, the disease most commonly linked with this awful partnership has been typhus, and typhus has become known as the archetypal famine fever. The aetiology of the disease has, however, rarely been examined in its historical context; as a result, historians have often misinterpreted its significance. In one recent article, for example, the disease was treated as an indicator of urban famine, of the extent to which the nutritional status of the Lancashire textile operatives was reduced by the Cotton Famine of the 1860s. ${ }^{1}$ In the nineteenth century, however, epidemics of typhus occurred in both times of stress and times of prosperity: unlike its cousin, relapsing fever, typhus is not a primary indicator of "true, nutritional famine".

Why did typhus disappear as a significant cause of death in the late nineteenth century? The disease was almost certainly endemic in pockets of cities across Britain in the eighteenth and early nineteenth centuries; from time to time there were epidemic outbreaks. What were the different factors that permitted the survival of the disease, stimulated epidemics, and finally led to its virtual disappearance in the 1870s? The commonly-assumed causal link between typhus and famine, or at least malnutrition, raises the question of dearth and living standards in the nineteenth century. The harvest-related subsistence crisis had vanished by the late eighteenth century; but do typhus epidemics indicate periods of dearth in nineteenth-century cities? Or was typhus's survival rather a question of hygiene? For the urban historian H. J. Dyos, typhus was an indicator of "dirt and destitution"; for Thomas McKeown, of malnutrition and low levels of personal hygiene. ${ }^{2}$ The answer is perhaps more complex: in a recent analysis of the European subsistence crisis of $1740 \mathrm{John}$ Post has argued that the links between food shortages and disease are more social than nutritional, that typhus is not an indicator of famine per se, but the consequence of social dislocation

*Anne Hardy, D.Phil., 22 Norham Road, Oxford OX2 6SF.

${ }^{1}$ D. Oddy, 'Urban famine in nineteenth-century Britain', Econ. Hist. Rev., second series, Feb. 1983, 37: 83 .

${ }^{2}$ H. J. Dyos, 'Some historical reflections on the quality of urban life', in David Cannadine and David Reeder (editors), Exploring the urban past. Essays in urban history by H. J. Dyos, Cambridge University Press, 1982, p. 72; Thomas McKeown, The modern rise of population, London, Edward Arnold, 1976, pp. $126,132,141$.
\end{abstract}


produced by harvest failure and distress. ${ }^{3}$ In such social crises, patterns of human behaviour alter; and increased mobility, domestic crowding and reduced personal hygiene result in epidemics. The behaviour of epidemic typhus in the nineteenth century supports this argument: the disease survived as long as social dislocation continued to be an intermittent feature of urban life, before rising and stabilizing real wages reduced the impact of economic upheavals on the lives of the working classes.

The language of urban crisis, of subsistence crisis, and of urban famine, generally appears in the historiography of the pre-industrial world, ${ }^{4}$ and is rarely applied to the nineteenth century. Historical debates about dearth and disease in the later eighteenth and nineteenth centuries centre on long-term issues, especially that of the extent to which improving - or stationary, or regressing-nutritional status influenced longterm trends in mortality from a range of endemic and epidemic diseases. ${ }^{5}$ In this debate, the mortality crises which continued to occur in individual cities, and the diseases which caused them, have received relatively little attention. ${ }^{6}$ Yet local studies may help our understanding of the mechanics of mortality change. Recent American research shows a correlation between short-term variations in urban mortality and the business cycle. The relationship is said to hold for both major epidemics and other diseases, and to be closely related to the pattern of European immigration: ${ }^{7}$ the epidemiological peaks illustrate the pattern of social and economic dislocation. Although this model is not entirely applicable to Britain, typhus is a disease of social dislocation, and its survival as an epidemic disease in England as late as the 1860s reflects not simply or necessarily hunger, but the complex social consequences of the inherent instability of an emergent industrial economy. ${ }^{8}$

If "urban crises" are seen as continuing into the nineteenth century, the circumstances in which typhus epidemics occurred may throw further light on mortality decline, and on the role of nutrition in this decline. This paper contends that typhus has a significance beyond nutritional levels. In terms of social history, Victorian typhus illustrates the social and economic insecurity of urban life up to the 1870 s, and the way

${ }^{3}$ John D. Post, Food shortage, climatic variability, and epidemic disease in preindustrial Europe; the mortality peak in the early 1740s, Ithaca, Cornell University Press, 1985; see also, idem, 'Climatic variability and the European mortality wave of the early 1740s', J. interdisciplinary Hist., summer 1984, 15: 1-30.

${ }^{4}$ Among a large literature, see for example, Peter Clark and Paul Slack, English towns in transition, Oxford University Press, 1976; Charles Pythian-Adams and Paul Slack, Urban crisis or urban change?, Milton Keynes, Open University, 1977; John D. Post, The last great subsistence crisis in the Western world, Johns Hopkins University Press, 1977; Paul Slack, The impact of plague in Tudor and Stuart England, London, Routledge and Kegan Paul, 1985, chapter 3.

${ }_{5}^{5}$ The literature includes F. W. Notestein, 'Population-the long view', in T. W. Schultz (editor), Food for the world, Chicago University Press, 1945, pp. 36-57; T. McKeown and Record, 'The decline of mortality in the 19th century', Population Stud., November 1962, 16: 98-122; McKeown, op. cit., note 2 above; A. B. Appleby, 'Nutrition and disease: the case of London, 1550-1750', J. interdisciplinary Hist., summer 1975, 6: 1-22; and the essays in the following Special Issues of $J$. interdisciplinary Hist.: 'Hunger and history', autumn 1983, 14, no. 2, and 'Population and history', spring 1985, 15, no. 4.

${ }^{6}$ Of the diseases which caused such crises, only cholera has been examined in detail. Cholera incidence is unrelated to nutritional status, and the disease was, like plague before it, an "invader": the term is used by Slack, op. cit., note 4 above, p. 14.

${ }^{7}$ R. Higgs, 'Cycles and trends of mortality in 18 large American cities, 1871-1900', Explor. Econ. Hist., 1979, 16: $381-408$.

${ }^{8} \mathrm{~L}$. D. Schwarz, 'The standard of living in the long run: London, 1700-1860', Econ. Hist. Rev., second series, 1985, 38: 32 . 


\section{Typhus in the Victorian city}

in which local economic conditions helped to determine outbreaks of disease; on the medical side, typhus's independence of nutritional status explains both its unpredictable appearances, and its disappearance from England at a time when the nutritional- and, probably, the hygienic level of the "submerged tenth" remained relatively unchanged. ${ }^{9}$

By the nineteenth century, typhus had become an essentially urban disease of sporadic outbreaks, in England and elsewhere. Throughout the century, Liverpool in particular continued to provide "a habitation and a name" for the disease. ${ }^{10}$ Nevertheless, in the 1870 s typhus mortality entered a decline which can now be seen to have been final. The social associations of typhus suggest reasons for its disappearance, but do not fully explain its epidemic pattern. In an attempt to understand why epidemic typhus disappeared in the later nineteenth century, circumstances in London, a city where the disease was almost endemic and repeatedly epidemic in the earlier part of the century, are here examined more closely. London experienced a major, but final, typhus epidemic in 1861-69. Of four previous epidemics during the century, three had been associated with economic depression, and the other with the potato famine of $1847-48 .^{11}$ The epidemic of 1861 began without any obvious trigger; indeed, it began in London in December 1861, but in Lancashire in October 1862. It is clear that in the 1860s London was a city under stress; this condition was not without parallel in other English cities, but it was unrelated to any wider, national economic crisis.

Gareth Stedman Jones has shown that there was a continuing economic crisis in London's East End in the 1860s. It began with the final decline of the silk-weaving industry, was compounded by the collapse of the Poplar ship-building industry in 1866, and its social effects were aggravated by house demolitions making way for factory- and warehouse building, improvement schemes, and railway construction. ${ }^{12}$ The last was not limited to the East End, and in 1860 distress had been increasing generally among London's working population as a result of building trade strikes. At this time, the national economy had barely begun to recover from the effects of the Crimean War. Average real wages, which declined sharply during the war years, returned to normal in $1859-60$, but were undermined by bad weather and poor harvests in 1860-2 and again in 1866-8. ${ }^{13}$ National concern focused on the Lancashire textile districts suffering from the effects of the Cotton Famine; and the crisis in London went almost unremarked, except by the medical press, hospital workers and the recently appointed Medical Officers of Health, whose duties were intimately connected with the condition of the people. ${ }^{14}$

\footnotetext{
${ }^{9}$ For brief recent surveys of standards of living in the later nineteenth century, and the survival of the "submerged tenth", see E. H. Hunt, British labour history 1815-1914, London, Weidenfeld and Nicholson, 1981, pp. 73-129; Michael S. Teitelbaum, The British fertility decline, Princeton University Press, 1984, pp. $37-43$.

${ }^{10}$ Lancet, 1896 , ii: 548 .

11 See note 57 below.

12 G. S. Jones, Outcast London, Oxford, Clarendon Press, 1971, chapters 3-5.

13 B. R. Mitchell and P. Deane, Abstract of British historical statistics, Cambridge University Press, 1962, pp. 343, 498; Jones, op. cit., note 12 above, pp. 44-6.

${ }^{14}$ Lancet, 1863, i: 422 . The London Medical Officers of Health took up their duties in the city's civil parishes in 1856 .
} 
The London building trades strikes beginning in 1859 were among the first serious manifestations of the Nine Hours Movement which had emerged in Liverpool in 1846. In 1859, the London master builders resorted to a lock-out of those men who would not pledge themselves not to join a trade union. The strike, or lock-out, lasted from 21 July 1859 to March 1860. Twenty-four thousand men were said to have been locked out; by the end of September some 14,000 were receiving allowances from the conference of the trade societies. ${ }^{15}$ The allowances were far from adequate, however, and as the means and credit of the men failed, the effects of the lock-out were felt more widely: small shopkeepers, for example, instead of taking $£ 9-10$ weekly from building-trades families, took no more than $£ 2-3$. As long as there was bread, the Registrar-General observed, the children had it, but weakened, cold and ill-clad, they died in unusual numbers towards the end of the year. ${ }^{16}$

In the spring of 1861 , when the masters tried to introduce a system of payment by the hour, the workers struck again. This time, the strike lasted barely a month. The 1859 strike and the cold winter of 1860-1 had lowered the resources of both men and unions; such masters as Lucas and Kelk, under contract for the Great Exhibition building for 1862 , were anxious to avoid any protracted argument. By 20 April, the strike was at an end. ${ }^{17}$ The cumulative effect of the strikes was probably to weaken the economy of working class London generally. There was scarcely a district of the city in which, by 1861, these trades did not form a substantial proportion of the working population: between 7.5 and 11.5 per cent of the males over twenty years old. ${ }^{18}$

1861 also saw the beginning of clearances preparatory to three major railway projects, affecting central and east London. The Charing Cross Railway's new junction at Red Cross Street, with an extension to Cannon Street, displaced 557 persons; the North London Railway's extension from Kingsland to Broad Street displaced between four and five thousand; the Metropolitan Railway's extension from Smithfield to Finsbury Circus displaced $1,100 .{ }^{19}$ In Southwark, South London, two major railway operations, in 1859-64 and 1860-64, forced over 7,700 persons to move. ${ }^{20}$ In north London, the demolition of the Agar Town slum to make way for St Pancras Station in 1862-4, sent waves of dislocation through Marylebone, St Pancras and St Giles. ${ }^{21}$ By 1862 , London's major working-class areas, in the southern, central and eastern districts, were all subjected to large scale railway clearances. The slum-clearance and street-building operations of the Metropolitan Board of Works added to the problem. ${ }^{22}$ Both developments were quick to take effect: as early as 1863 , Medical Officers of Health were aware of increased overcrowding. In 1867, Dr Pearce of Bethnal Green estimated that in some cases rents had increased by as much as 50 per cent. ${ }^{23}$

\footnotetext{
${ }^{15}$ For the background to these strikes, see Richard Price, Masters, unions and men: work control in building and the rise of labour 1830-1914, Cambridge University Press, 1980, pp. 15-54.

${ }^{16}$ Twenty-second annual report of the Registrar-General, [PP, 1861, XVIII, p. 41].

17 The Times, 23, 26, 28 March 1861; 20 April 1861.

${ }^{18}$ The district percentage figures were: East, 7.5; Central, 7.6; South, 9.2; West, 10.6; and North, 11.5 per cent of males over 20 .

${ }^{19}$ H. J. Dyos, 'Some social costs of railway building in London', J. transp. Hist., 1957, 3: 21. See also idem, 'Railways and housing in Victorian London', J. transp. Hist., 1955, 2: 11-21.

${ }^{20}$ Ibid.

${ }^{21}$ MOAR St Pancras, 1862, 6; 1864, p. 8.

22 Dyos, 'Railways', op. cit., note 19 above; Jones, op. cit., note 12 above, pp. 162-3, 215-17.

${ }^{23}$ MOAR St Giles, 1863, p. 16; MOAR Shoreditch, 1863, p. 11; MOAR Bethnal Green, 1867, p. 4.
} 


\section{Typhus in the Victorian city}

The impact of overcrowding in London in the 1860 s can be illuminated, to some extent, by modern research. Density in American cities has been found to have a uniformly positive and statistically significant effect on mortality. Household density is thought to aggravate such stresses as do exist in low income populations, which in certain circumstances affect mental and physical health. In nineteenth-century cities, erratic employment, nutritional deficiencies, insecure living standards, high immigration levels of people with no previous experience of urban life, and overcrowding created "optimal conditions for pervasive morbidity and high mortality". ${ }^{24}$ In the London of the late $1860 \mathrm{~s}$, these conditions existed in no mean degree, and were aggravated by ruthless slum-clearance and coincident depression in the working-class economy. Provincial immigration probably added to the problem. It has been estimated that immigration into London rose in 1861-71 to 331,000 , over 286,000 in $1851-61$. It rose again, to 498,000 in $1871-81$, falling only to 402,000 in $1881-91 .^{25}$

The year 1861-62 marked the beginning of an "artificial" subsistence crisis, one not related to food shortages and excessively high prices. It was nonetheless real, and in the forms of social dislocation, increased overcrowding and rising rents, it lasted for several years, in fact until about 1870 , when the initiation of new railway operations began to slacken in pace. Between 1867 and 1872, no major works were begun; ${ }^{26}$ and it was during these years that the great typhus epidemic, which had afflicted the poorer districts of the city since the end of 1861 , finally came to an end.

\section{II}

Typhus, the "spotted fever" of sixteenth-century England, the "gaol fever" of the eighteenth, the "Irish fever" of the mid-nineteenth, has a long and distinguished history intimately associated with the social upheavals caused by war and famine. ${ }^{27}$ Although long confused with typhoid, the two diseases have distinct behavioural patterns: typhoid is endemic, typhus epidemic. The eighteenth century, from circa 1708 to 1815 , constituted the last "great typhus period". After 1815 , the disease only once attained its former scale of diffusion in Europe, in 1846-7. ${ }^{28}$ In the first half of the nineteenth century there were numerous localized outbreaks of the disease, but after 1850, except in particular circumstances (notably in Eastern Europe during World War I), epidemic frequency in Europe declined markedly. ${ }^{29}$

The universal decline of epidemic typhus makes the analysis of reasons for its disappearance problematic. Hans Zinsser, admitting the problem, pointed to the

\footnotetext{
${ }^{24}$ R. Higgs and F. D. Booth, 'Mortality differentials within large American cities in 1890', Hum. Ecol., 1979, 7: 353-69.

${ }^{25}$ H. A. Shannon, 'Migration and the growth of London, 1841-91. A statistical note', Econ. Hist. Rev., April 1935, 5: 84.

${ }^{26}$ Dyos, 'Social costs', op. cit., note 19 above, p. 27.

27 See Hans Zinsser's classic, Rats, lice and history, London, George Routledge and Sons, 1935.

${ }^{28}$ August Hirsch, Handbook of geographical and historical pathology, vol. 1, London, New Sydenham Society, 1883, pp. 554-5.

29 Zinsser, op. cit., note 27 above, pp. 290-301.
} 


\section{Anne Hardy}

"coöperative forces of modern civilized society"; to the development of intensive agriculture and rail transport, which prevented the prolonged isolation of famine districts; to the rise of modern diagnostic and preventive medicine; and especially to the fact that wars, in this period, were of short duration and affected relatively circumscribed areas. ${ }^{30}$ Charles Creighton, referring to England only, argued for improved nutrition as a factor. ${ }^{31}$ George Rosen favoured slum clearance, the regulation of lodging-houses, provision of baths and washhouses, the increased use of cotton clothing which could be more frequently washed, as well as rising living standards, as the principal causes of decline. ${ }^{32}$ McKeown and Record distinguished environmental improvements, especially improved water supplies, and better diet as salient features. ${ }^{33}$ In a recent study, Bill Luckin largely dismisses these factors, and points to the pattern of Irish immigration into England. ${ }^{34}$ Finally, John Post's important analysis suggests the reasons for the behaviour of the disease in Europe as a whole.

The infectious organism of typhus, Rickettsia prowazeki, appears to be invariably louse-borne among human beings. Like dysentery, typhus appears wherever poverty, crowding and insanitary conditions prevail, in times of social dislocation, and principally in the winter months. The incubation period of the disease in man is ten to fourteen days. Infected lice invariably die, usually within seven to twelve days; and although the infection is not transmitted to their eggs, it can survive in the dust of their faeces for months or even years. ${ }^{35}$ The human louse is sensitive to temperature, preferring that of $29^{\circ} \mathrm{C}$ which it finds in the folds of clothing worn by a healthy person. Lice therefore tend to leave febrile patients, and corpses, in favour of those with normal temperatures, but die in a few hours if exposed to room temperature. They are easily killed by common antiseptics, and once a typhus patient has been deloused and bathed, he cannot transmit the infection by contact to others. Case-fatality in man varies from 10 to 40 per cent in untreated cases; nineteenth-century case-mortality is estimated to have been between 20 and 45 per cent. Typhus fatality rises sharply with age, but one attack confers immunity on survivors for many years. ${ }^{36}$

Throughout the nineteenth century, however, doctors and public health officials worked in total ignorance of the true nature and origins of typhus. Only in 1909 did Charles Nicolle and his colleagues at the Institut Pasteur in Tunis show that infection is

30 Ibid., p. 292.

${ }^{31}$ C. Creighton, A History of epidemics in Britain, vol. 2, Cambridge University Press, 1894, p. 215.

32 G. Rosen, 'Disease, debility and death', in H. J. Dyos and M. Wolff (editors), The Victorian city, vol.2, London, Routledge and Kegan Paul, 1973, pp. 633-4; idem, A history of public health, New York, M D Publications, 1958, pp. 339-40.

${ }^{33}$ McKeown and Record, op. cit., note 5 above, p. 116.

${ }^{34}$ Bill Luckin, 'Typhus and typhoid in London', in R. Woods and J. Woodward (editors), Urban disease and mortality in 19th-century England, London, Batsford Academic, 1984, pp. 111-116.

${ }^{35}$ British encyclopedia of medical practice, second edition, vol. 12, London, Butterworth, 1952, p. 392.

${ }^{36}$ Medical information on typhus has been drawn principally from William Topley and Graham Wilson, Principles of bacteriology, virology and immunity, vol. 3, 7th edition, ed. G. R. Smith, London, Edward Arnold, 1984, ch. 77; F. H. Top and P. H. Wherle, Communicable and infectious diseases, St Louis, MO, Mosby, 1981, ch. 57; F. L. Horsfall and I. Tamm, Viral and rickettsial infections of man, London, Pitman, 1965; P. D. Hoeprich (editor), Infectious diseases, Maryland, Harper and Row, 1977. The estimate of nineteenth-century case fatality was made by Bill Luckin, op. cit., note 34 above, p. 104. 
spread by the body-louse ingesting the infected blood of the typhus patient. ${ }^{37}$ After about a week, the rickettsiae have multiplied in the louse gut and are excreted in the faeces. Healthy persons are generally infected through the skin, by scratching, and sometimes by the inhalation of dust containing dried but still viable rickettsiae. Transmission may thus occur through either individual louse infestation, or the inhalation of infected dust. Modern treatment of the disease is with a broad spectrum of antibiotics; prevention by the control or elimination of the insect vector, by reducing louse infestation to a minimum and preventing overcrowding. In 1939-45, for example, such long-acting insecticides as DDT were impregnated into clothing, and sprayed over houses and potentially infected areas. ${ }^{38}$

In the 1860 s, no such certainty existed. The diagnostical distinction between typhoid and typhus, made by William Jenner in 1847-51, had become generally accepted. There was general agreement, too, over the circumstances of typhus transmission: in overcrowded localities and in times of destitution. ${ }^{39}$ The disease was broadly recognized as contagious-hence the perceived dangers of overcrowdingbut disagreement over the finer points of its behaviour continued. In particular, Charles Murchison, the greatest fever expert of the $1860 \mathrm{~s},{ }^{40}$ thought that typhus might be independently generated, de novo, in conditions of squalor and overcrowding. ${ }^{41}$ This belief was disputed by colleagues, and gradually became discredited after Murchison's death: in many places, overcrowding and squalor were constant, whereas typhus was only occasional. ${ }^{42}$ By the $1880 \mathrm{~s}$, medical men still concerned with typhus were almost certain that it was transmitted exclusively by contagion, but they had no positive means of proving their contention. ${ }^{43}$

The disagreement over spontaneous generation does not invalidate Murchison's observations on the behaviour of typhus. It was generally known that typhus frequently appeared without warning, and without the traceable contacts on which contagion should depend. Murchison chose to explain this phenomenon by a hypothesis of spontaneous generation; others assumed that the contagion was imported in a fashion that defied detection. ${ }^{44}$ Observation similarly indicated the role of infected clothes, and suggested that of infected housing. ${ }^{45}$ However, there could be no clear explanation until the role of the louse and its faeces as vector, and the dangers of infected dust, were understood. Following the distinction of typhoid

\footnotetext{
${ }^{37}$ Topley and Wilson, op. cit., note 36 above, p. 575. See also James Busvine, Insects, hygiene and history, London, Athlone Press, 1976, pp. 233-239.

38 Ibid., p. 578.

${ }^{39}$ Margaret Pelling, Cholera, fever and English medicine, Oxford University Press, 1976, p. 283, notes that medical interest in typhus declined from the second quarter of the nineteenth century, as the disease waned in epidemic importance.

${ }^{40}$ Charles Murchison (1830-1879): Assistant Physician, London Fever Hospital, 1855; Physician, 1861-70; author of $A$ treatise on the continued fevers of Great Britain (first ed. 1862).

${ }^{41}$ C. Murchison, Continued fevers, 3rd ed., W. Cayley, (ed.), London, Longmans, Green \& Co, 1884, pp. 99-104.

42 Ibid., p. 99.

${ }^{43}$ See George Buchanan and J. Spear in the Sixteenth annual report of the Medical Officer to the Local Government Board, [PP, 1887, XXXVIII, pp. 635, 959-62]; Alex Collie, On fevers, London, H. K. Lewis, 1887, pp. 105-7.

44 Ibid.

45 MOAR St Olave, 1867-8, p. 23.
} 
and typhus, and in the absence of any bacteriological certainty, differing explanations of the observed behaviour of the disease were perhaps inevitable.

Observations, however, led to a fundamentally correct preventive approach to the disease, of which thorough disinfection was the basis. From its earliest days, the London Fever Hospital followed this policy with regard to typhus- "the infectious malignant fever" of the metropolis - and besides removing infected individuals, attended to the disinfection of apartments, furniture and clothing in affected localities. ${ }^{46}$ For the rest of the century this remained the accepted method of dealing with typhus, and was generally found effective, provided it was thoroughly carried out. In the district of St Olave in the 1860s, for example, houses were disinfected with Calvert's powder, carbolic acid and chlorine, and infected bedding (a recognized vehicle of typhus) was disinfected before being burnt. ${ }^{47}$ This, with the isolation of patients as far as possible, was the standard preventive treatment. Even so, the remedy was flawed. Disinfection might be incomplete, and there were often difficulties with contacts: in practice it was not easy to secure the disinfection of persons, and clothes, exposed to typhus. Preventive authorities frequently, and generally fruitlessly, urged the necessity of establishing houses of refuge where personal purification could be carried out. ${ }^{48}$ The London Fever Hospital early found fumigation and white-wash to be inadequate in certain areas. ${ }^{49}$ In some cases, the final remedy was closure of affected houses. In Orange Street, St Saviour, where eleven typhus cases occurred in January 1887, disinfection proved ineffectual, and the series of cases only came to an end when all the inhabitants were removed to a temporary shelter, and all the houses in the street closed. ${ }^{50}$

The recognition of typhus as a separate entity from about 1850 makes it possible here to treat it as a unified disease. This approach may be criticized on the grounds that the Registrar-General did not distinguish the disease from typhoid and simple continued fever until 1869, and that statistics and diagnoses before that date, and to some extent after it, are unreliable. There is clear evidence, however, that even before William Jenner distinguished the different fevers in 1849 , many physicians were aware of their differing natures, and of the different treatments they required. ${ }^{51}$ After 1849 , the distinction between these fevers was very commonly accepted and made. In his report for 1848 , the physician of the London Fever Hospital outlined the clinical distinction between typhus and typhoid, and from then on, the two diseases were regularly separated in the Hospital's admissions- and mortality figures. ${ }^{52}$ From the 1850 s, writers and correspondents in the Lancet commonly used "typhus" and "typhoid" correctly, and although there were still those who claimed that the two were varieties of one fever, the argument had died away by the $1860 \mathrm{~s} .{ }^{53}$ The diagnoses of the London Fever Hospital, in

\footnotetext{
${ }^{46}$ W. F. Bynum, 'Hospital, disease and community: the London Fever Hospital 1801-1850', in C. Rosenberg (editor), Healing and history, New York, Dawson Science History Publications, 1979, p. 101.

${ }^{47}$ MOAR St Olave, 1867-8, p. 23; MOAR St Saviour, 1871, p. 7.

48 Buchanan and Spear, op. cit., note 43 above, p. 960.

49 Bynum, op. cit., note 46 above p. 106.

${ }^{50}$ MOAR St Saviour, 1887, pp. 28-9.

51 W. Jenner, Lectures and essays on fevers and diptheria, 1849 to 1879, London, Rivington, Percival \& Co., 1893; Murchison, op. cit., note 41 above, pp. 31-51.

${ }_{52}$ London Fever Hospital annual report [LFHAR] 1848, p. 9.

${ }^{53}$ Lancet, 1855 , i: 436 ; 1856, i: 159 ; 1857 , i: 504.
} 


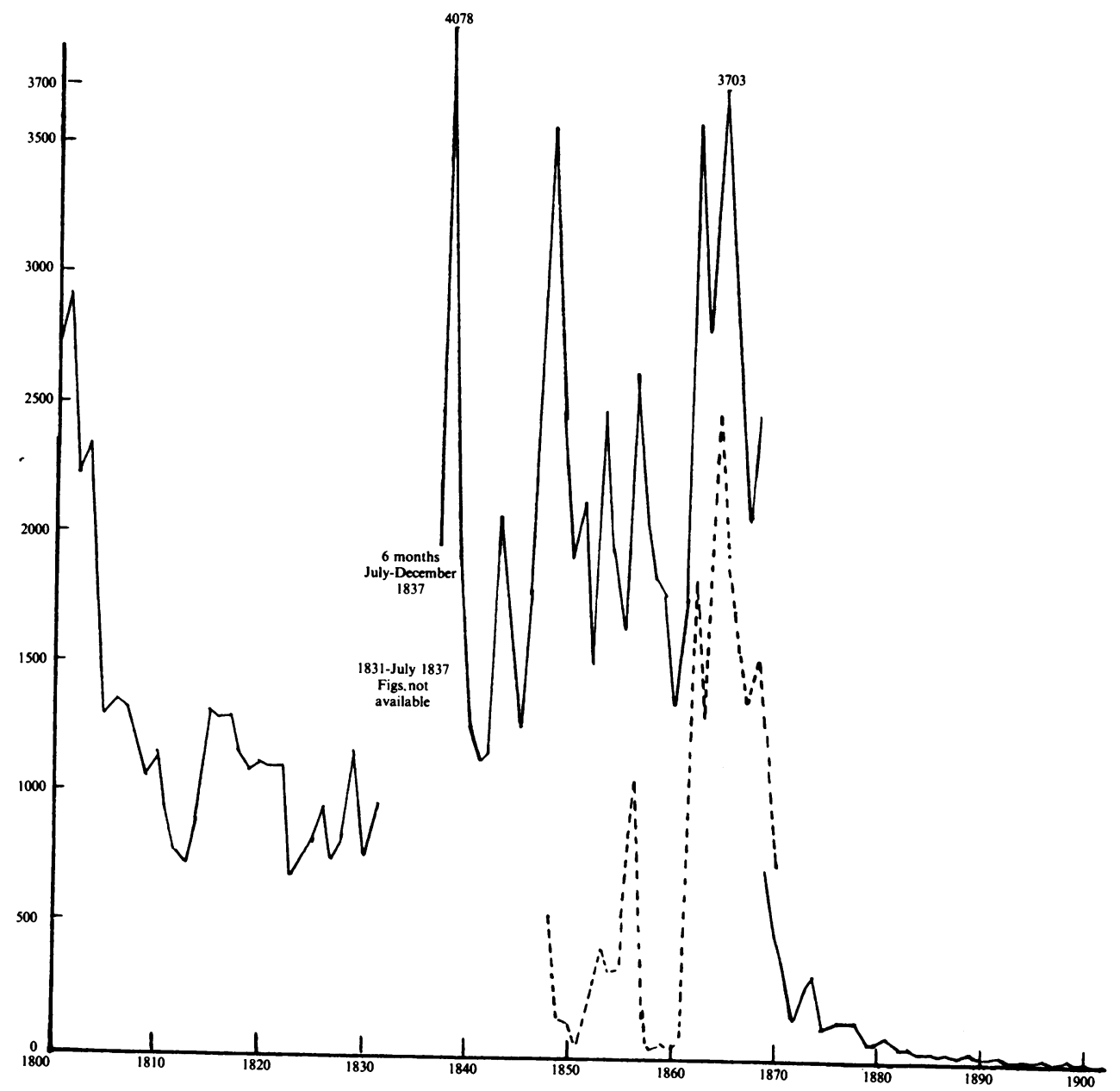

FIGURE 1: Typhus in London, 1800-1900

1800-1830: "Typhus" (most fever) deaths (source: J. Marshall, The mortality of London, 1832)

1837-1868: "Typhus" (typhus and typhoid) deaths (source: Annual Reports of the Registrar-General)

1869-1900: Typhus deaths (source: Annual Reports of the Registrar-General)

- - - Typhus cases admitted to the London Fever Hospital, 1848-1870 (source: London Fever Hospital Annual Reports) 
particular, are likely to be reliable: the Hospital's physicians were among the foremost experts in diagnosis of these diseases, and its admissions figures for the two diseases were regarded by the Registrar-General as the best index of their relative presence in London. ${ }^{54}$ In 1868, Carl Wunderlich's publication of the results of his temperature researches finally provided a reliable determinant for the diagnosis of typhoid, in distinction to typhus; ${ }^{55}$ this was probably the basis on which the Registrar-General officially admitted the distinction between the two diseases in 1869. Errors in diagnosis, or terminology, continued to occur during the $1870 \mathrm{~s}^{56}$ and they demonstrate that agggregate mortality figures should be treated with caution.

The variety of factors involved in the epidemiology of typhus make unlikely any monocausal explanation of its virtual disappearance from England, indeed from Europe, in the nineteenth century. Epidemics occurred widely in Britain in between 1816 and 1819, following the end of the Napoleonic Wars, and in 1847-8, consequent on poor harvests and the potato famine. In London, there were additional epidemics in 1826 , following the financial crisis of 1825 ; in 1836, again during major cyclical depression; in 1856, after the end of the Crimean War and coincident depression; and in the period 1862-70. ${ }^{57}$ The 1860 s also saw major typhus epidemics in Liverpool (1862-67) and Glasgow (1861-70); and various lesser outbreaks in Lancashire in the autumn of 1862, during the early, acute phase of the Cotton Famine, and in Aberdeen, Greenock and Dundee. Epidemics apart, however, the disease was never entirely absent; indeed deaths from typhus continued to be registered down to 1900 (figure 1). ${ }^{58}$ Similarly, the register of admissions to the London Fever Hospital show that even during non-epidemic years, the disease was active in the city (figure 1). Although the epidemic conditions of the disease disappeared in the years after 1870, the materies morbi, ever diminishing, remained.

The distribution of typhus in London was, until the 1870s, linked to specific areas within the central, southern and eastern registration districts. Within these areas, certain localities, possibly never free from fever, were popularly designated "fever nests" from at least the $1830 \mathrm{~s} ;{ }^{59}$ they were generally recognized by the public health

${ }^{54}$ LFHAR 1872, p. 5; Lancet, 1859, i: 337.

${ }^{55}$ L. G. Stevenson, 'Exemplary disease: the typhoid pattern', J. Hist. Med., 1982, 37: 168.

${ }^{56}$ Lancet, 1878 , i: 323 ; ii: 414.

57 In general, the pattern of typhus epidemics closely follows that of economic depression. Thus, in the last decade of the eighteenth century, the depressions of 1794-5 and 1797-1800 were accompanied by typhus: Creighton, op. cit., note 31 above, pp. 156-7, 159-62; Murchison, op. cit., note 41 above, pp. 38-9. Exceptionally, the severe depression of 1840-2 did not produce a typhus epidemic in England, only one of relapsing fever. This was perhaps because the great epidemic of 1836-8 had eliminated adult susceptibles.

58 Not all deaths from typhus were erroneously registered in the later period. In 1890 , for example, there was an outbreak in St Olave, Southwark, and there were outbreaks in Cardiff (1892-3), Edinburgh (1898), Dundee (1900), and elsewhere.

${ }_{59}$ This phenomenon is impossible to substantiate closely. By the time accurate statistical series for streets and houses become available, the disease was so far in retreat that the location of cases is almost meaningless. The spot maps published by the Metropolitan Asylums' Board from 1892 onwards thus show an annual scattering of generally isolated cases across London, from which no pattern of infection can be deduced. In St George, Southwark, small groups of cases suggest a possible lingering of some local source of infection, but in St Giles only one case of typhus was notified between 1892 and 1900 . Total annual typhus notifications for the city were by this time in single figures. It should be noted that the published figures are not corrected for the misdiagnoses which certainly occurred. For the earlier part of the century, however, Dickens's observation (in Bleak House, Harmondsworth, Penguin Books, 1971, p. 364) of "fever houses" where "for 


\section{Typhus in the Victorian city}

authorities as the particular haunts of typhus. ${ }^{60}$ In the parish of St Giles, for example, the courts and alleys around Great Wild Street and Drury Lane were notorious. ${ }^{61}$ In East London, Whitechapel was the "nucleus of the metropolitan fever field", while among the southern districts, St Olave and St George Southwark were prominent. ${ }^{62}$ In these districts and others like them, it was apparently true that particular houses constituted the foci of infection. William Rendle, for twenty-four years the Poor Law medical officer in St George Southwark, and subsequently, if briefly, its Medical Officer of Health, declared that there were comparatively few centres of infection for typhus, and that most typhus cases came from certain houses. ${ }^{63}$

One such house, 131 Drury Lane in St Giles, was described in detail in a Lancet report of 1865 as "a capital illustration of the method of preserving typhus". A large, three-storey building with a dirty plaster front, it housed a second-hand clothes shop in the basement. A notice advertised rooms to let, notwithstanding that the whole house was full of typhus. Every room contained two or three people. The disease had begun with a second-floor family whose daughter, living in nearby Drury Court, had caught the infection from a fellow lodger there. For two months the disease spread from family to family at 131 Drury Lane, but did not interrupt the various occupations pursued under that roof, including the manufacture of trinkets for ladies' heads and dresses. ${ }^{64}$

If such houses were not cleansed and disinfected once typhus cases had occurred, infected louse faeces shaken out of clothing and bedding might lie undisturbed for years, awaiting the arrival of further non-immune occupants, or the disturbance caused by increased crowding, to generate fresh cases. As late as 1879, Dr Lovett of St Giles could declare that every outbreak of typhus in the district had been traced to Lincoln Court and Orange Court, Drury Lane. ${ }^{65}$ More than forty years earlier, Gerhard observed a similar phenomenon in Philadelphia. ${ }^{66}$ Charles Murchison's belief in the spontaneous generation of typhus, based on particular instances, also suggests that the houses themselves were implicated. ${ }^{67}$ The role of housing in sustaining the disease was probably assisted by the rapid turnover of inhabitants in quarters such as St Giles. In 1861, for example, the London City Mission found that in one month half the families in Monmouth Court, St Giles, had been replaced. ${ }^{68}$ Unrecognized cases, particularly among children, who are not seriously affected by the disease, undoubtedly also sustained typhus in particular districts and among a particular class. ${ }^{69}$

months and months" the inhabitants were carried out dead and dying by the dozens, should not be forgotten.

${ }^{60}$ MOAR St George-the-Martyr, 1866-7, p. 6.

61 Lancet, 1865, ii: 522.

62 Ibid., pp. $267,602,657$.

${ }^{63} \mathrm{~W}$. Rendle, London vestries and their sanitary work, London, John Churchill, 1865, pp. 11-12; Lancet, 1869 , i: 737.

${ }^{64}$ Lancet, 1865 , ii: 522 .

65 Ibid., 1879, ii: 793.

${ }^{66}$ L. G. Wilson, 'Fevers and science in early nineteenth-century medicine', J. Hist. Med., 1978, 33: 401.

${ }^{67}$ Murchison, op. cit., note 41 above, pp. 99-104.

${ }^{68}$ Lynn H. Lees, Exiles of Erin, Manchester University Press, 1979, p. 58.

${ }^{69}$ Collie, op. cit., note 43 above, p. 107. 
The persistence of typhus in particular localities, and its spread into new ones, ${ }^{70}$ were determined by specific factors: the character of the population living there, their dirt and the filthy conditions of the houses in which they lived, and particularly overcrowding. Medical Officers repeatedly pointed out that overcrowding, lack of ventilation and want of cleanliness were the chief causes of the disease, and that these characterized the dwellings of the poorer classes. ${ }^{71}$ The Medical Officer for Liverpool went further. In a survey of the disease in Liverpool over the years 1862-6, he discovered that 93 per cent of the city's typhus deaths occurred among the weekly-wage earning class, who inhabited courts and alleys "where sanitary provisions are conspicuously absent". Of the remaining typhus deaths, 5.4 per cent took place among the small shopkeeping class, and 1.3 per cent (some 100 individuals) among scripture readers, medical men, relieving officers, pawnbrokers and undertakers, who all risked contact with typhus patients in one way or another. ${ }^{72}$

In London, weekly-wage earners constituted a large proportion of the working class, and most were in occupations that experienced seasonal slackness, with under- or unemployment. Among this class, it was a common emergency economy for families and friends to double up in accommodation. ${ }^{73}$ When a seasonal depression coincided with severe weather, the living conditions of this class deteriorated, leaving them more vulnerable to contagious disease. In the early 1860 s, increased crowding in habitations infested with typhus exposed more people to infection.

To this background of overcrowding and dirt should be added a third factor. Charles Murchison thought that overcrowding, lack of ventilation, and destitution with starvation were the most important causes of typhus. ${ }^{74}$ All writers on the subject agreed with him, including the eminent German epidemiologist, Rudolph Virchow. ${ }^{75}$ Creighton, as mentioned above, thought that supplies of cheap food, fuel, and clothing were chiefly responsible for the virtual disappearance of the disease. Modern epidemiologists are less certain as to the relationship between nutritional standards and typhus susceptibility. ${ }^{76}$ Again, the link between typhus and nutrition is only indirect. Hungry people - who need not be starving, or even malnourished-feel the cold more. Personal hygiene is affected: cold people do not like undressing. In such conditions, lice find congenial hosts.

The spread of typhus was determined more by these factors than by actual nutritional levels. Although the disease did not spread among the middle- and upperclasses, it had no trouble in developing in well-nourished hosts when offered the

\footnotetext{
${ }^{70}$ This was the case in Poplar. See below notes 80,81 .

${ }^{71} M O A R$ Mile End Old Town, 1859, p. 6; MOAR Westminster, 1864-5, p. 14; MOAR Camberwell, $1864-5$, p. 25 . For the mechanics of typhus transmission in overcrowded conditions, see W. P. MacArthur, 'The medical history of the famine' in R. D. Edwards and T. D. Williams (editors), The Great Famine, Dublin, Browne and Nolan, 1956, pp. 271-2.

72 Lancet, 1867, ii: 608.

73 Jones, op. cit., note 12 above, pp. 117-18.

74 Murchison, op. cit., note 41 above, p. 52. In the final analysis, Murchison regarded overcrowding as the single most important element: ibid., pp. 340-1.

${ }^{5}$ Lancet, 1867, ii: 701; 1868, i: 561, 572. This reference was to the second edition of Virchow's work. For the development of Virchow's ideas, see Paul Weindling, 'Was social medicine revolutionary?', Bull. Soc. soc. Hist. Med., June 1984, 34: 13-18.

${ }_{76}$ Post, Food shortage, op. cit., note 3 above, pp. 272-3; Luckin, op. cit., note 34 above, p. 113.
} 
opportunity. This was made abundantly clear during the Irish epidemic of $1848-9,{ }^{77}$ and the 1860s epidemic also offers ample evidence. In April 1862, two Poor Law medical officers in St George-in-the-East died of typhus; in 1866, London society was shocked by the death of the distinguished Dr Henry Jeaffreson, of St Bartholomew's Hospital, from typhus; in 1868, the Reverend Henry Lance, who had served notably during the cholera epidemic, died of typhus caught while visiting the poor. In 1869 the Lancet observed, on the occasion of the deaths of two Rotherhithe doctors from typhus, that the disease was "relentlessly" claiming many members of the profession. By 1872, typhus was "that scourge of our profession". ${ }^{78}$ Middle-class victims were almost certainly infected by inhaling contaminated dust; they never contracted relapsing fever, for which contact with the body fluid of the louse is required. ${ }^{79}$

Poor nutrition was therefore not a primary determinant of typhus outbreaks, and typhus cannot be accepted as an unqualified indicator of urban famine. The disease continued to exist in household dust and among children in pockets where squalor maintained, and an adult population which was generally immune limited, its activities. Unusual local population movements could activate the epidemic propensity of this residual infection. Thus social distress could start the typhus sequence where indigenous disease existed, or where it was imported. But hunger or distress were not the sole causes of social dislocation in Victorian cities.

The appearance of typhus in places experiencing good times confirms the importance of dislocation, as opposed to distress. The marked revival of the disease in the East London district of Poplar in the $1860 \mathrm{~s},{ }^{80}$ for example, was probably due to sudden, "stress" overcrowding. Poplar enjoyed a surge of prosperity in the early 1860 s, during which the numbers employed in the ship-building yards there increased from 13,000 in 1861 , to 27,000 in $1865 .^{81}$ Greenock similarly experienced a typhus epidemic when overcrowding accompanied prosperity. ${ }^{82}$ The typhus outbreaks in Whitechapel and St Olave in 1873 occurred during a "period of unprecedented prosperity" and in midsummer. ${ }^{83}$ It seems likely that the dislocation caused by the Shoreditch improvement schemes in the East End, from $1872,{ }^{84}$ and by demolitions for Peabody Trust developments in Southwark in the early $1870 \mathrm{~s}$, ${ }^{85}$ was responsible for these outbreaks which were, according to the Lancet, by no means on an epidemic scale. ${ }^{86}$

Typhus admissions to the London Fever Hospital increased considerably in the spring after the severe winter of $1860-1$, but it was not until mid-December that the

${ }^{77}$ MacArthur, op. cit., note 71 above, p. 278-9.

${ }^{78}$ Lancet, 1862, i: 448; 1866, ii: 680; 1868, i: 102; 1869, i: 306; 1872, i: 276.

${ }^{79}$ MacArthur, op. cit., note 71 above, p. 280.

${ }^{80}$ Luckin, op. cit., note 34 above, p. 110.

81 Jones, op. cit., note 12 above, p. 102.

82 Collie, op. cit., note 43 above, p. 107

${ }^{83}$ Lancet, 1873, ii: 22.

84 See Percy J. Edwards, History of metropolitan street improvements 1855-1897, London County Council, 1898, pp. 45-51. It was admitted that 2,920 persons had been displaced by these operations.

${ }_{85}$ J. N. Tarn, Five per cent philanthropy, Cambridge University Press, 1973, pp. 49-50.

${ }^{86}$ Lancet, 1873, ii: 212. 


\section{Anne Hardy}

disease became epidemic. It then spread rapidly: in January 1862 the number of Fever Hospital admissions for typhus was 140 , among the highest monthly totals in its history. ${ }^{87}$ From 1862 until 1870 the number of typhus admissions to the Hospital, and the number of 'fever' deaths registered in London, remained at epidemic level (figure 1). The epidemic of 1862-70 was almost certainly self-generated, not introduced to the city from elsewhere. The disease had been introduced from Ireland in 1847-8, and it was widely assumed by the 1860 s that typhus was generally the result of Irish importation. ${ }^{88}$ In 1856, however, there was no typhus epidemic in Ireland; the London outbreak was an isolated one. ${ }^{89}$ Similarly, in 1862 there was no evidence to support a suggestion of Irish origin. The disease did not become epidemic in Ireland until 1863;90 of 992 typhus cases admitted to the London Fever Hospital in the first six months of 1862 , only forty-four were Irish, and of these, all but five had lived in London for more than three months and none had recently arrived from Ireland. ${ }^{91}$ Almost all the first cases admitted were unemployed male tramps with no fixed address, who had suffered from want for many weeks. Many of them had been only a few weeks in London, ${ }^{92}$ but the ten-day incubation period of typhus indicates that they contracted it in London itself. The Irish were not responsible for introducing epidemic typhus in 1856 and 1861 , nor can the decline in typhus be linked to any reduction in Irish immigration. Although the proportion of Irish-born persons living in London fell steadily after 1851, the actual numbers arriving from Ireland increased in the 1870 s and 1880s. The Irish contributed 14,000 immigrants to London in the decade $1851-61 ; 7,000$ in $1861-71$; 19,000 in 1871-81; and 20,000 in 1881-91.93

Charles Murchison argued that, while the Irish did not import typhus to London in all instances of epidemics, they contributed substantially in another way. It was well known, he wrote, that by the "immigration of the lower classes of Irish, pauperism and habits of overcrowding and personal uncleanliness - the main causes of the prevalence of typhus-have been greatly augmented in the large towns of Britain". 94 In the twelve years 1855-1867, 4.9 per cent of London Fever Hospital admissions were Irish-born, against the 75 per cent who were natives of London. A high proportion of the latter were, however, children of Irish parents or of Irish extraction. ${ }^{95}$ Murchison's views were based on his experience at the Hospital. The second Medical Officer of Health for St Giles, Dr Ross, shared Murchison's view of Irish domestic habits. The Irish were, he wrote, "destitute of any notion of the proper use of the domestic appliances instituted for cleanliness and decency in towns". Ross's experience was firsthand: in the Great Wild Street-Church Street area, within the St Giles fever nest, was an Irish colony with

${ }^{87}$ Ibid., 1862, i: 207-8.

${ }^{88}$ Luckin, op. cit., note 34 above, pp. 106-7.

${ }^{89}$ Murchison, op. cit., note 41 above, p. 57; Hirsch, op. cit., note 28 above, p. 556; Lancet, 1863, i: 422. Although typhus was certainly introduced by the Irish in 1846, the situation in English cities was such that the disease would probably have appeared within a relatively short time in any case: Creighton, op. cit., note 31 above, p. 205.

${ }_{90}$ Murchison, op. cit., note 41 above, p. 52.

91 Ibid., p. 55.

92 Ibid., pp. 58, 54.

93 Lees, op. cit., note 68 above, p. 58; Shannon, op. cit., note 25 above, p. 84 .

94 Murchison, op. cit., note 41 above, pp. 58-9.

95 Ibid., p. 57. 


\section{Typhus in the Victorian city}

a fairly constant number of changing individuals. ${ }^{96}$ Modern historians confirm the squalor and destitution of the Irish slums: there can be little doubt that they were ideal habitats for typhus. ${ }^{97}$

From the spring of 1862 to November 1863, the typhus epidemic was confined to the poorest and most densely populated parts of the city ${ }^{98}$ In 1862,53 per cent of the cases admitted to the London Fever Hospital came from eight districts, with St George-inthe-East contributing 179 cases, St Pancras (where the Agar Town slum had just been razed) 162 , and the City $157 .{ }^{99}$ In 1863 , nearly all the cases received by the Hospital were reported as having come, to date, from the most crowded areas, from Bermondsey, Lambeth, St George-in-the-East, Rotherhithe and the City. ${ }^{100}$ At the end of October 1863 it was observed that several parishes had experienced marked fluctuations in the incidence of the disease, but St George-in-the-East and St Pancras furnished the "most constant and equable supply" of patients. A month later patients were still being received mainly from the south and east (from Rotherhithe, Bermondsey, Lambeth, St Saviour, and St George-in-the-East), but there were indications that the disease was spreading. More cases were arriving from Shoreditch and the City, and others were being brought in from Hackney and Kensington, which had not furnished cases for months previously. ${ }^{101}$ By 1864 , the epidemic was more generally diffused through the city, although its focus remained the poorest areas. ${ }^{102}$ In 1865 , it was prevalent in the southern and central districts, but from 1866 on, the focus shifted to the east, where it remained until the epidemic began to wane. In 1868 , for example, typhus cases were coming to the Hospital principally from Stepney, Whitechapel, Shoreditch and other East End districts. ${ }^{103}$

The London Fever Hospital's records do not provide a straightforward picture of the epidemic's distribution. Not only were milder cases generally treated at home, but although the Hospital was the only metropolitan institution for typhus victims before October 1871, cases were not automatically sent to the Hospital from all the districts in the metropolis. Some parishes preferred to save the expense of treatment and deal with cases in their own workhouse infirmaries. Significantly, Whitechapel and St Giles were both in this class. ${ }^{104}$ Whitechapel provided perhaps the most notorious example of the practice. As its Medical Officer of Health observed in 1868, it was probably inhabited by the poorer classes to a greater extent than any other district in London; ${ }^{105}$ it was said

${ }^{96}$ MOAR ST Giles, 1870 , p. 13. See also Lees, op. cit., note 68 above, p. $66-7$.

${ }^{97}$ Lees, op. cit., note 68 above, pp. 71-87; M. O. Tuathaigh, 'The Irish in nineteenth-century Britain', Trans. $R$. Hist Soc., Sth series, 1981, 31: 154.

${ }^{98}$ Lancet, 1863, ii: 422.

${ }^{99}$ LFHAR, 1862, p. 6.

100 Ibid., 1863, p. 7.

101 Lancet, 1863, ii: 603.

102 LFHAR, 1864, pp. 6-7.

${ }^{103}$ Ibid., 1868, p. 189; Luckin, op. cit., note 34 above, Table 5.1, pp. 108-9.

${ }^{104}$ LFHAR, 1866, p. 13. Three other districts also avoided the LFH charges: Mile End, Lewisham and Poplar. St Giles began sending cases to the LFH on 1 April 1865; Whitechapel on 1 December 1865. Poor Law cases were charged by the LFH at the rate of $1 \mathrm{~s}$. a day until 1868. Thus the cost to, for example, St George-in-the-East and St Pancras of typhus cases in 1862 came to approximately $£ 161$ and $£ 145.8 \mathrm{~s} .0 \mathrm{~d}$. respectively.

${ }^{105}$ MOAR Whitechapel, vol. 2, 1868, p. 12. 


\section{Anne Hardy}

to be the centre of the metropolitan fever field. ${ }^{106}$ In the decade $1851-60$, the district contributed the largest number of metropolitan fever deaths, and the Lancet suspected it of playing a "too prominent" part in fostering the great 1861-70 epidemic. 107

In 1865, it was estimated that of Whitechapel's 9,000 houses, 5,000 were let out as lodging-houses, each containing an average of three families. The parish's population in 1861 was 79,000; a density of 195 persons per acre. In the Poor Law year (Lady Day, i.e. 25 March, to Lady Day) 1864-65, 37 per cent of this population received indoor or outdoor relief. ${ }^{108}$ Until 1866, the Whitechapel authorities made no use of the London Fever Hospital, and typhus victims were treated either in the workhouse or at home. ${ }^{109}$ Both practices contributed to the spread of infection. The Lancet's own investigations had clearly shown that the treatment of typhus victims in workhouse infirmaries resulted only too frequently in extensive "in-house" epidemics; ${ }^{110}$ home treatment was equally recognized as only multiplying the foci of infection. Vestry policy on the treatment of typhus cases was only one element in the epidemic spread of the disease, and it was clearly not the most important. ${ }^{111}$ Nevertheless, in the context of the social dislocation occurring among London's working class during the 1860s, the failure of vestries to ensure the effective isolation of cases at the London Fever Hospital contributed to the epidemic impetus. ${ }^{112}$

The waning of the epidemic in the later 1860s was not due to any change in the virulence of the disease. In a recent essay analysing the decline of typhus, Bill Luckin examined and convincingly dismissed the possibility of autonomous change in the nature of the disease. ${ }^{113}$ Explanation lies elsewhere, and in this respect the current analysis differs from the Luckin interpretation. The ending of the London typhus epidemic in 1870-1 was sudden, but no more so than in 1848 or in 1857 . In both those years, contemporary observers attributed the disappearance of the epidemic to the restoration of normal market conditions. ${ }^{114}$ In $1870-1$, the situation was not so simple and Murchison, for example, had no retrospective explanation to offer. ${ }^{115}$ Bread prices stabilized in the early $1870 \mathrm{~s}$, but they did not fall dramatically. ${ }^{116}$ It is possible that, having affected some 190,000 persons in the inner city in the years $1862-69$, typhus had

106 Lancet, 1865, ii: 656.

107 Ibid.

108 Ibid.

109 MOAR Whitechapel, 1865 , p. 5

110 Lancet, 1865, ii: 656.

111 Neverless, vestry policy was probably important in sustaining the endemic level of the disease. The London Fever Hospital's inability to eliminate typhus from certain courts may have been due to repeated importation from uncontrolled areas of the city, or to inefficiencies of disinfection. See Bynum, op. cit., note 46 above, p. 106.

112 This element should not be exaggerated. Many typhus cases undoubtedly remained unknown to the authorities. In 1869, the first year for which such a calculation is possible, admissions to the London Fever Hospital constituted 17 per cent of estimated London cases; in 1870, 13 per cent. This calculation is based on the contemporary assumption of a case-fatality rate of 1 in 10 . The London form of the disease was less virulent than that in Lancashire, where mortality was circa 23 per cent: Fifth Annual Report of the Medical Officer to the Privy Council, [PP, 1863, XV, Appendix 2, pp. 229, 304].

${ }_{113}$ Luckin, op. cit., note 34 above, pp. 113-14.

114 Murchison, op. cit., note 41 above, pp. 51-3; Creighton, op. cit., note 31 above, p. 205.

115 Murchison, op. cit., note 41 above, p. 54.

116 Mitchell and Deane, op. cit., note 13 above, p. 498. 


\section{Typhus in the Victorian city}

diminished the pool of accessible, non-immune potential victims; ${ }^{117}$ but the conclusion of the major railway works was probably critical. While general levels of overcrowding did not diminish, during the 1870s London experienced a period of comparative quiet and prosperity, ${ }^{118}$ which probably reduced the incidence of short-term, expediency overcrowding.

Urban crises did not disappear after 1870. Cyclical depression, unemployment and distress, aggravated by the exceptionally severe winter, returned in $1878-9 .{ }^{119}$ During the 1880 s the city experienced a particularly prolonged period of social crisis, at its worst between 1884 and $1887 .{ }^{120}$ Throughout this period, overcrowding in the working class areas of the city scarcely abated. Average real wages, however, began to rise steadily, ${ }^{121}$ and the post 1870 London crises differed from those earlier: there were no bread riots or semi-violent distress, and there were no typhus epidemics. The disease continued to decline steadily (figure 1).

Yet typhus had declined substantially before. In the years 1803-15 it was markedly absent in England. ${ }^{122}$ Between 1858 and 1860, it was so rare in London that there were serious plans to convert the London Fever Hospital into a general hospital. ${ }^{123}$ The decline of typhus in the 1870s was not so sudden or dramatic that it was regarded by contemporaries as anything more than a temporary respite. After all, even the 70 odd deaths registered in London in 1879 and 1880 represented, in terms of contemporary calculation, some 700 cases. ${ }^{124}$ Indeed the distress in London in these years caused the Lancet to warn against the outbreak of epidemics. ${ }^{125}$ The final decline of typhus in London dates not from the early 1870 s, but from the late 1870 s and early 1880 s. The role of the nutritional factor is indirect; but important developments in the sanitation of housing, water supplies, and hospital treatment, ${ }^{126}$ and changes in the nature of urban social dislocation, both occurring in the years around 1870, were probably critical to the subsequent history of typhus.

117 The figure of 190,000 has been arrived at by taking the total typhus admissions to the LFH in the years $1862-9$ and assuming, on the basis of note 112 above, that these represented 15 per cent of the total number of cases. The importance of provincial immigration in replenishing the non-immune pool was perhaps limited: such immigrants tended to settle in the outer suburbs of the city. Jones, op. cit., note 12 above, p. 130. In 1870, Murchison observed that the marked decline in typhus was "to some extent" due to the elimination of susceptibles ( $L F H A R 1870$, p. 8), but he did not offer any retrospective confirmation of this observation.

118 Jones, op. cit., note 12 above, pp. 276-7.

119 Ibid., pp. 46, 277.

120 Ibid., pp. 281-2.

${ }^{121}$ Mitchell and Deane, op. cit., note 13 above, pp. 345-6. See also the recent assessments by Hunt, op. cit., note 9 above, and Teitelbaum, op. cit., note 9 above.

122 Creighton, op. cit., note 31 above, pp. 162-7.

${ }^{123}$ LFHAR, 1861, p. 6; Murchison, op. cit., note 41 above, p. 53.

124 In 1878, the Lancet calculated on the basis of 25 per cent mortality, among 179 completed cases at the Metropolitan Asylums Board hospitals, that there were 636 cases of typhus in London in 1877. Lancet, 1878, i: 324 . There were 151 registered typhus deaths in London in 1877, giving, on this basis, 604 cases.

125 Lancet, 1879 , i: $63,385-6$.

126 Given modern assessment of the aetiology of the disease, I cannot agree with Luckin (op. cit., note 34 above, p. 113) that sewerage was a necessary condition for the eradication of epidemic typhus. Human urine and faeces can only transmit typhus if they contain blood: this method of transmission is not considered important by any of the authorities cited in note 36 above. 
Very little improvement occurred in the housing conditions of the poorest of the London working classes in the later nineteenth century, ${ }^{127}$ but developments in the later 1860 s and 1870 s may have been significant to typhus. In the first place, there were the demolitions for railways and street improvement, and after the passing of the Artisan Dwellings Act of 1875 these were supplemented by vestry- or Medical Officer of Health-sponsored clearance schemes specifically aimed at fever nests. In St Giles, for instance, the old fever dens of Great Wild Street and Little Coram Street were swept away by 1883, and the clearance of two more (Shelton Street, Drury Lane, and the Colonnade) was contemplated. ${ }^{128}$ In 1887 , the Lancet went so far as to remark that the St Giles clearances had cleared typhus from London. ${ }^{129}$

Meanwhile, although the provisions for the regulation of common lodging houses in the Sanitary Act of 1866 had proved almost unworkable, sanitary departments were taking steps under existing legislation to remedy the worst of the superficial conditions as far as possible. Specific sanitary defects were rectified under the Nuisance Removal Acts; more generally, houses were cleaned and lime-washed. In St Martin-in-theFields, Dr Beale "nearly succeeded" in having every tenement house cleansed and whitewashed at least once a year during the late 1860s. Conditions in some courts, he admitted, continued to be "disgraceful", but he stated that he found the cleaning and repairing of tenement houses less difficult every year. In 1867, notices to cleanse had been attended to with "tolerable exactness", and in no instance had it been necessary to call on the magistrates for aid. ${ }^{130}$ In St Giles, 12,573 improvement orders were issued between 1875 and 1883 , and 7,770 houses cleansed-an average of 971 per annum. ${ }^{131}$ Since this district had only 3,968 inhabited houses in 1881 , apparently some 24.5 per cent of its housing stock was cleansed every year.

The combination of fever-nest demolition and regular cleaning may have gone some way to removing the old typhus habitats. If low-level non-epidemic typhus was sustained between epidemics by the survival of Rickettsia prowazeki in dried louse faeces, and by the continuous flow of newcomers into (and out of) poor lodgings, the regular cleaning of this type of housing would break the cycle of transmission. In Liverpool, for example, it was said that regular cleaning and supervision had eliminated typhus from the city's common lodging houses between 1848 and $1863 .{ }^{132}$ It may also be relevant that in the years 1868-79, the London Medical Officers of Health had to contend with three successive major outbreaks of contagious diseases recognized as epidemic: scarlet fever, in 1868-70; and smallpox, in 1870-3 and 1876-8. Direct results of these epidemics were widespread house-to-house visitations in search of contacts and unvaccinated children; and equally widespread disinfection of the homes, bedding and clothing of victims throughout London, both on a scale never experienced before. The

\footnotetext{
127 Jones, op. cit., note 12 above, pp. 174-8; A. S. Wohl, The eternal slum, London, Edward Arnold, 1977, chapter 2.

128 MOAR St Giles, 1883, p. 73. Shelton Street went in 1889: ibid., 1889, p. 21.

129 Lancet, 1887, i: 632.

${ }^{130}$ MOAR St Martin, 1867 , p. 19. Beale found that these houses rapidly became dirty again: ibid., 1868, p. 18.

131 MOAR St Giles, 1883, p. 73.

132 Seventh Annual Report of the Medical Officer to the Privy Council, [PP, 1865, XXVI, appendix 8, p. 478].
} 


\section{Typhus in the Victorian city}

implementation of these preventive measures was undoubtedly particularly thorough in the poorest areas which were the most vulnerable to sanitary supervision.

In these years, increased provision was also made to enable the poor to cleanse their bodies, clothes and homes themselves. Bill Luckin has argued that, although per capita water consumption in the eastern and northern districts rose from twenty to twenty-four gallons a day by the mid-1870s, it was not until the 1890 s that more than 50 per cent of this population had access to company water, or were provided with a more than intermittent supply. ${ }^{133}$ In fact, company-supplied constant service was widely provided in the east, although less so in the northern districts, by $1880 .{ }^{134}$ The East London Water Company was a pioneer in this respect. As early as 1868, Dr Liddle recorded that the poorest parts of hitechapel were probably better provided with water than "any other district in London". ${ }^{135}$ In 1869, the East London Compnay resolved to extend constant supply throughout its district, and had achieved this object within its metropolitan area by 1883 .

Although in the poorest courts water was often supplied by standpipes, not laid on to houses, the convenience of a constant supply and the alteration in patterns of water usage which this entailed became widespread in East London in the 1870s. It is difficult to assess how far the availability of a constant supply improved personal cleanliness. ${ }^{136}$ While it is clear from evidence presented before the 1884 Royal Commission on Housing, for example, ${ }^{137}$ that an inadequate water supply continued to be a difficulty in some of the poorer districts of the city, the extension of constant water supplies may have contributed to household cleanliness, and thus to the typhus ecology.

Hospital provision was the third area in which significant developments occurred. Although the pressure which the 1860s epidemic brought to bear on workhouse services caused many districts to resort early to London Fever Hospital treatment for their typhus cases, this was an expensive proceeding for economy-minded Guardians to sanction. The situation altered with the passing of the Metropolitan Poor Act of 1867 , which introduced rate equalization as a means of spreading the financial burden of London's poor more evenly. Money spent on the hospitalization of infectiousdisease victims could be reclaimed from the Common Poor Fund, thus removing

${ }^{133}$ Luckin, op. cit., note 34 above, p. 112 . It is possible to disagree with the last part of this statement, since the sources on which it is based stem from the London County Council [LCC] - a body notoriously involved in the politics of the water question. Aggregate water supply figures given in the 1890 s generally refer to 'Water London', an area considerably larger than Registration London: Nineteenth Annual Report of the Local Government Board, [PP, 1890, XXXIII, Appendix B no. 2, p. 237]. The LCC commonly seems to have used the statistics of Water London as if they referred to the smaller area of Metropolitan London. The wider issues of the politics of London water in the 1890s have not as yet been satisfactorily analysed. But see A. Shadwell, The London water supply, London, Longmans Green and Co., 1899, especially chapter 1; and A. K. Mukhopadhyay, 'The politics of London water', London J., 1975, 2: 207-12; idem., The politics of London water supply 1871-1971, unpublished Ph.D. dissertation, London University, 1972.

${ }^{134}$ Anne Hardy, 'Parish pump to private pipes: London's water supply in the nineteenth century', in W. F. Bynum (editor), Living and dying in London 1700-1900, London, Routledge, [in press].

135 Lancet, 1868, i: 273.

136 Martin Daunton, House and home in the Victorian city, London, Edward Arnold, 1983, p. 42, notes that one bath and one clothes' wash a week were still customary in working-class households well into the twentieth century.

${ }^{137}$ Report of the Royal Commission on the Housing of the Working Classes, [PP, 1884-5, XXX, p. 13]. It should be noted that local authorities had no power to compel the supply of water for domestic purposes, only for sanitation. Domestic water provision thus remained a frequent difficulty in small houses whose 


\section{Anne Hardy}

inhibitions about excess spending. ${ }^{138}$ The number of admissions to the London Fever Hospital certainly rose sharply in 1868 (typhus admissions increased to 449, from 254 in the previous year, in the three months June-August), but as the numbers of typhoid admissions and of registered fever deaths also rose, the impact of the new legislation in this area cannot be quantitatively assessed. Given the aetiology of the disease, however, increased hospitalization was likely a more effective preventive measure for typhus than for such genuinely infectious diseases as scarlet fever and smallpox. During the 1870s, moreover, hospital provision for fever patients was extended with the opening of the Metropolitan Asylums Board hospitals. ${ }^{139}$

Finally, during the 1870 s, the rate of railway demolitions eased. Although railway displacements continued to be made in the 18 hese were not on as large a scale, or quickly effected, as those which took place in the central and eastern districts in the early to mid-1860s. Between 1867 and 1885 , some 19,000 persons were displaced by railway schemes, compared with 37,000 between 1859 and $1867 .{ }^{140}$ Pressure on housing in the centre did not ease, because railways, street improvements, slum demolition and warehouse construction continued relentlessly, ${ }^{141}$ but the impact of these operations was more diffused and the degree of social dislocation less acute than in the previous decade.

In this sense, and with the temporary stabilization of the metropolitan working class economy, London's crisis of the 1860 s, and with it the essential conditions for the continuance of epidemic typhus, passed in the 1870s. During that decade crucial environmental improvements eventually, although perhaps not finally until the 1880 s, dislodged the disease from its seats of residual survival. Rising real wages meanwhile took the edge off urban distress in the later years of the century, and prevented large-scale 'stress' overcrowding. Poverty and misery did not disappear in London, but bread riots and semi-violent distress did. ${ }^{142}$

\section{IV}

The importance of local conditions, and of social dislocation in particular, in creating an environment favourable to epidemic typhus is confirmed by what can be ascertained of the behaviour of the disease in towns and cities other than London. Edinburgh's non-manufacturing population was vulnerable to typhus in seasons of general distress, but social dislocation generated by specific factors was rare. Nevertheless, when in 1826 the city experienced failures in building speculations which disturbed its internal economy, typhus became seriously epidemic. ${ }^{143}$ In the early 1850s, Dr James Brown, practising his newly-acquired skills in the diagnostic

\footnotetext{
owners were reluctant to pay $3 \mathrm{~d}$. a week for it: ibid., q. 9632; in any case the supply was generally of cold water only.

${ }_{138}$ Metropolitan Poor Act 1867, 30 \& 31 Vict. c. 60, ss. 61-69.

139 G. M. Ayers, England's first state hospitals and the Metropolitan Asylums Board, London, Wellcome Institute of the History of Medicine, 1971, part I.

140 Dyos, 'Railways', op. cit., note 19 above, p. 14.

141 Jones, op. cit., note 12 above, chapter 8; Wohl, op. cit., note 127 above, chapter 2.

142 Jones, op. cit., note 12 above, pp. $45,54$.

143 Murchison, op. cit., note 41 above, p. $45,54$.
} 


\section{Typhus in the Victorian city}

distinction of fevers, searched diligently in Rochester, Chatham and Strood for cases of typhus and relapsing fever. The towns were in constant contact with London, and were on the tramp routes. Typhoid was endemic, but neither of the "famine fevers" occurred, because, Brown concluded, there was very little overcrowding or destitution. ${ }^{144}$ When typhus appeared at Preston in July 1862 , it had been absent from the town for fifteen years; contemporaries traced the origin of the first cases to "overcrowding", ${ }^{145}$ which was probably caused by stress. The disappearance of the disease, from January 1863, probably indicates the extent to which the charitable relief which poured into the area succeeded in ameliorating the textile operatives' distress: this was also the opinion of contemporary experts. ${ }^{146}$

During the 1860s, typhus was seriously epidemic in Liverpool and Glasgow, as well as in London. Unlike London, however, both cities had direct connections with Ireland, and both suffered continuously from typhus. Once again, however, it is clear that the initial epidemic impetus could not have come from Ireland, as the epidemic only developed there subsequently. The circumstances of Glasgow are obscure, although as late as 1886 the city's Medical Officer of Health wrote that it was never free of typhus. ${ }^{147}$ Contemporary opinion differed as to the cause of the Liverpool epidemic: the Medical Officer of Health thought it due to stress, following the Cotton Famine, which went largely unrelieved because the city was outside the central Lancashire textile district. ${ }^{148}$ George Buchanan, investigating for the Privy Council, disagreed but was unable to reach any firm conclusion as to the epidemic's causes. ${ }^{149}$ There seems to have been no extraordinary distress in Liverpool in the later $1860 \mathrm{~s},{ }^{150}$ but it may be significant that this decade saw railway operations advance into the heart of the city. ${ }^{151}$ The parish of Liverpool lost 2,717 inhabited houses and 31,389 inhabitants in the years $1860-71$, and its excess of deaths over births stood at 2,660 per annum. ${ }^{152}$ Typhus was already endemic in the city, and local circumstances are likely to have been responsible for its epidemic escalation in these years.

Typhus continued to exist in the centres of most large towns until the $1880 \mathrm{~s},{ }^{153}$ but showed little inclination to escalate in these years of general prosperity, except briefly in 1874. The return of less settled conditions in the early 1880s brought some indications of a resurgence. Various small outbreaks of the disease in the northern towns came incidentally to the Local Government Board's notice in these years, causing anxiety in the Medical Department. Finally, George Buchanan, then Medical

\footnotetext{
144 Lancet, 1855, i: 436.

145 Murchison, op. cit., note 41 above, p. 54; Fifth Report of the Medical Oficer to the Privy Council, [PP, 1863, XXV, p. 18].

146 George Buchanan, 'Recent typhus in Lancashire', Trans. epidem. Soc., 1862, 2: 23.

${ }^{147}$ Lancet, 1886, ii: 620 . The current argument's relevance to conditions in Glasgow is not illuminated by Olive Checkland and Margaret Lamb (editors), Health care as social history: the Glasgow case, Aberdeen University Press, 1982.

148 Lancet, 1867, ii: 608.

149 Seventh Annual Report of the Medical Officer to the Privy Council, [PP, 1865, XXVI, appendix 8, pp. 481-5].

150 Ibid., p. 481.

151 J. R. Kellett, The impact of railways on Victorian cities, London, Routledge and Kegan Paul, 1969, p. 201.

152 Lancet, 1875, i: 96-7.

153 Ibid., 1878, i: 323.
} 
Officer to the Local Government Board, mindful of "the conditions of so many industrial communities", arranged for these outbreaks to be studied more closely in 1885-6. The investigation proved revealing. In five of the seventeen towns investigated, the disease was shown "with strong probability" to have been imported. ${ }^{154}$ None of the importations were from Ireland, although in five cases outbreaks were in north-eastern seaports where Irish communication was a reality. At Carlisle, Gateshead and Oldham, tramps were the vehicle of infection; at Quarry Bank, hop-pickers returning from Herefordshire; at Middlesbrough, a discharged prisoner. Importation was also suspected in Sunderland. ${ }^{155}$ In Leeds, West Derby, and Hartlepool, it proved impossible to trace the origins of the outbreaks. All three occurred in very poor areas (in Leeds and Middlesbrough, the localities were Irish), and spread by recognized channels, among relatives, friends and neighbours. At Hartlepool, it was noted that poverty amounting to distress had been present in the winter of $1885-6$, because of the depressed state of the shipping industry; at Quarry Bank, a town dependent on the chain-making industry, trade had also been much depressed, and a strike had further reduced wages, when typhus appeared in a particularly insanitary district. ${ }^{156}$

In Maryport and Liverpool, eastern seaports with histories of typhus where free communication with Ireland might have been found to have been a crucial factor, the Board's Inspector Spear was not convinced of its significance. In Maryport, most of the frequent and "somewhat mysterious" reappearances of typhus could not be so explained. The Maryport outbreaks recurred in one poor quarter of the town where the lodging houses, the resort of sailors and dock labourers, were found. Nelson Street, in particular, saw repeated cases. In Liverpool, the Medical Officer of Health's inquiries only occasionally revealed importations from Ireland or elsewhere. Liverpool typhus, whether in its endemic or epidemic form, appeared within certain well-defined limits, in the older and generally low-lying districts towards the river, in South Toxteth ward and neighbouring localities. Here were long narrow streets, confined courts and cellar dwellings occupied by the poorest of the poor, mainly Irish unskilled labourers, who found a precarious livelihood in the docks, and their families. In these localities, Spear observed, typhus appeared to be indigenous, and most frequently an outbreak would appear to be linked with an earlier one, "or antecedent cases before unrecognised are found to have occurred amongst the children of the resident population (if the constantly shifting seething mass of squalid humanity may be so designated), and there all further trace is lost". 157

Typhus thus continued endemic, if generally submerged, in Liverpool until the later 1890s at least, with occasional epidemic outbreaks to testify to its survival. In London, the chance discovery of a typhus-nest in the district of St Olave, in 1890, suggests the possibility of a similarly submerged existence. ${ }^{158}$ The experience of Nelson Street,

\footnotetext{
154 The seventeen were Accrington, Carlisle, Flint, Gateshead, Hartlepool, Jarrow, Leeds, Liverpool, Maryport, Middlesbrough, Newcastle-upon-Tyne, Oldham, Quarry Bank, Salford, Sunderland, West Derby, and Warrington. See figure 2.

155 Spear, op. cit., note 43 above, p. 957.

155 Ibid., pp. $947,950$.

157 Ibid., p. 956.

158 This outbreak, of between thirty and fifty cases, occurred in Sard's Rents, a blind alley with a population of 211 and thirty houses which were mostly offensive from dirt and poor ventilation, old, and
} 


\section{Typhus in the Victorian city}

Maryport, is yet more instructive. Here Spear found reason to attribute the outbreak to "the revivification of long dormant household contagion". He discovered that Nelson Street contained a marine store dealer, whose proprietress admitted that she had often taken rags from fever-stricken houses. Her business had probably been the source of the many cases in the district over the years, and the culminating outbreak occurred when she moved house, and her contaminated rag-store was disturbed. ${ }^{159}$ In Carlisle and Salford, furthermore, difficulty had been experienced in avoiding recurring outbreaks in rooms supposed to have been disinfected; Spear warned particularly against the premature withdrawal of surveillance from infected localities. 160

The conclusions which Spear drew from his inquiries in 1886-7 illustrate the extent to which different factors operated in different areas, even within a limited period. He emphasized the difficulty of identifying the origin of most outbreaks, and noted that early cases were frequently so mild as to pass unrecognized, and that the habit of the disease was to "creep steadily on" for some time until multiple cases in different households combined to exert an "explosive force". Cases appeared amid destitution and squalor; he attributed the current relative inactivity of typhus to the comparative absence of distress. Spear himself seems to have favoured migration as the trigger for outbreaks, ${ }^{161}$ but the evidence of Maryport, Carlisle and Salford clearly suggests the importance of residual or dormant infection in some areas. The mildness of early cases also suggests continuing, submerged infection among child populations in some towns. This may have activated outbreaks among adults when the "ecological" balance of housing for the poor was disturbed in times of stress, as it was, for example, in Hartlepool and Quarry Bank in 1885-6. By this date, the degree to which outbreaks escalated often depended on the vigilance of the local health authorities: at Leeds, Hartlepool, Carlisle, Middlesbrough, Oldham, Newcastle, Flint and repeatedly in Liverpool, the disease became established through the neglect of unrecognized cases; but in Accrington, Warrington, Gateshead, Sheffield and Jarrow, and in Chelsea, Southwark and Camberwell where there were also episodes at this time, initial cases were promptly recognized and dealt with, so forestalling any considerable outbreak. ${ }^{162}$

Spear's inquiry, while it provides no evidence of serious Irish links, suggests that migration, household dust infection, and residual endemic typhus all contributed at times to epidemic outbreaks, but that the critical factor in epidemic escalation was often extraordinary distress caused by local economic factors and accompanied by social dislocation. ${ }^{163}$ In Liverpool, the disease was maintained among a poor population which, within certain geographical limits, was constantly mobile in squalid and overcrowded living conditions. In Maryport, similarly, the disease occurred

\footnotetext{
partly dilapidated. The first victims slept on bare floorboards which may have harboured infected dust. The Lancet spoke of Sard's Rents explicitly as "one more of the spots in London where typhus can maintain itself'. Lancet, 1890, ii: 406; see also MOAR St Olave, 1889-90, pp. 76-80.

159 Spear, op. cit., note 43 above, pp. 953, 960.

160 Ibid., p. 959.

161 Ibid.

162 Ibid., p. 960.

163 Ibid., p. 961.
} 


\section{Anne Hardy}

principally in an area of the town with a poor and highly mobile population. The predominance of ports among the towns studied in 1887 (see figure 2) may be explained by their greater vulnerability to imports, but also by their social structure. By their very nature, ports could not avoid the growth of quarters of cheap housing and a transitory and often disreputable population. Sanitary supervision was difficult in such quarters, and it was here that typhus stood its best chance of residual survival. Given its endemic survival in places such as Maryport and Liverpool, coastal traffic and ordinary population movements would ensure occasional outbreaks elsewhere, especially in other seaboard towns attracting a similar traffic and population. The origin of the 1887 outbreak at Carlisle, for example, was traced to Maryport, via a man who had travelled through Cumberland in search of work, while a prolonged outbreak at Workington in 1884 had spread by demonstrable links to Dearham, Maryport and Whitehaven. 164

\section{$\mathbf{V}$}

The disappearance of epidemic typhus from Victorian cities constituted a significant improvement in the living conditions of adult urban populations, and marks something of a watershed in urban health history. Rural immigrants to these cities had been especially vulnerable; now a major cause of their mortality was removed. In epidemic terms, life became considerably more secure for the urban poor and for the middle classes directly involved with them. For social and medical historians, the survival of epidemic typhus until the 1870s suggests the continuation of urban crises of the pre-industrial type, in which social dislocation was associated with epidemic disease, long after the towns had been released from harvest-related supply problems; as well as the significance of local economic conditions in determining disease behaviour. The disappearance of typhus represents, on the one hand, the arrival of structural, as well as economic and social, stability; on the other, the effectiveness of local public health programmes after 1870 .

Detailed analysis of the nineteenth-century typhus experiences of individual towns can alone confirm the hypothesis that social dislocation was the principal determinant of epidemic outbreaks. According to Murchison, the disease was not endemic on the Continent between epidemics as it was in Britain and, to an even greater extent, in Ireland. ${ }^{165}$ In England, industrial development and rapid urbanization from the later eighteenth century undoubtedly resulted in widespread stress among increasing urban populations, to an extent which may have paralleled the stress produced by warfare on the Continent. The conditions which sustained epidemic and endemic typhus in Ireland are still not elucidated fully, but urban stress and the low expectations of Irish urban immigrants may have been critical. To Murchison, Ireland's whole social and economic structure lay at the root of her typhus endemicity. ${ }^{166}$ Nevertheless, Irish importation of epidemic typhus into England was not crucial in determining explosions of the disease there. It was rather the social condition

104 Ibid., pp. 943, 947.

165 Murchison, op. cit., note 41 above, p. 57 .

166 Ibid., pp. 137-8. 


\section{Typhus in the Victorian city}

of individual cities that allowed the epidemic escalation of imported or residual endemic typhus; and the steady disappearance of typhus after 1880 reflects both the vigilance of health authorities, and the degree to which serious social and economic dislocation was modified in English cities in the closing decades of the nineteenth century.

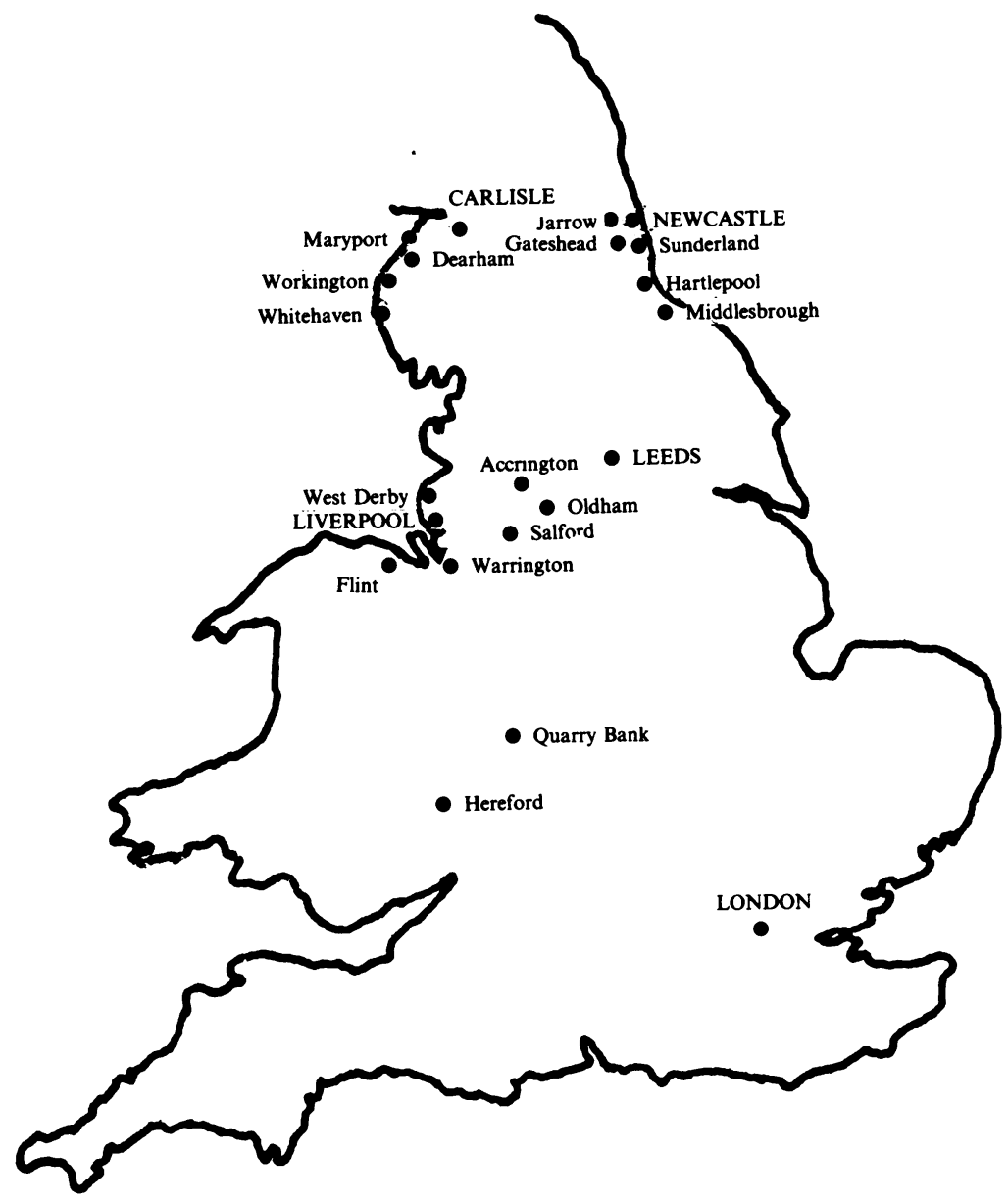

FIGURE 2

Map of Towns involved in Typhus Outbreaks 1885-1887 